\title{
Women Entrepreneur in Small Medium Enterprises (SMEs) and their Contribution on Sustainable Economic Development in Sindh
}

\author{
Dr.Abdul Latif \\ Chairman, Department of Management Sciences \\ Islamia University Bahawalpur, Pakistan
}

Muhammad Suhail Nazar

Assistant Professor

Department of Management Sciences, Islamia University Bahawalpur, Pakistan

Dr.Naimatullah Shah

Assistant Professor, Deptt: of Public Administration, University of Sindh-Jamshoro

Faiz Muhammad Shaikh

Assistant Professor, SZABAC-Dokri-Larkana, Pakistan

E-mail:faizanmy2000@hotmail.com

Received: June 8, 2011

Accepted: July 4, 2011

doi: $10.5539 /$ jsd.v4n4p230

\begin{abstract}
The article analyses the impact of women entrepreneur in small and Medium Enterprises on sustainable Economic development in Sindh. The rapid absorption of women into the labor market has been influenced by several factors. The rapid economic growth was due largely to important growth in the SMEs business, where substantial and proportionally larger increase of female workers has been registered. Among all sectors of the economy, the SMEs has recorded the highest growth rate during the last decade. The increase in the female labor force participation in SMES business may also be attributable to improving economic incentives in employment and policies favoring the employment of women. In addition, the combined effects of increased years of schooling, access to family planning services, improved maternal and child care, leading to arise in the average age at marriage, have allowed women to take advantage of the increased employment opportunities. Survey was conducted from 500 women in SMEs business in rural Sindh by using simple random technique from four districts, Shikarpur, Jacobabad, Kandhkot/Kashmore and Larkana Districts. Structural Questionnaire was the basic tool to find out the major challenges of rural women as an entrepreneur business. It was revealed that there is great potential of rural women is doing the various entrepreneur business like in Kandhkot, Jacobabad, Rali, Ajrak and Sindhi caps they are very much unique and they were generating income from there families. It was further revealed that the rural women is less confident and their husbands were always given them hard time once they are exposing them selves to out side the boundaries of the house. The biggest challenges which they were facing they were doing all business in house, lack of marketing facilities, Karo Kari criminal activities and they were deprived from the basic rights. This study contributes and explores the Rural Women challenges in SMEs business and how these critical unethical problems we can overcome like KARO KARI, and other various social issues.
\end{abstract}

Keywords: Women, Participation, SMEs, Probit model

\section{Introduction}

Women entrepreneur play a significant role in the economic development by contributing 3\% in GDP share of Pakistan. The greater growth potential lies in the modern high technology industries but it is also present in the labor-intensive industries of the traditional Small Enterprise sector and in the services that support it. "Young people in the future are more likely to end (therefore) should be working in organizations closer to the entrepreneurial mode" (Allan Gibbs). It is a worldwide phenomenon that Small Enterprises are an important part of a nation's economic and social structure. "Enterprise is the antithesis of command and control". On a global perspective Small Enterprises have acquired a significant stature in the economic development of a country. Globalization has put Small Enterprises directly in the limelight. Small Enterprises are increasingly a major force for national economic growth. The entrepreneurs who drive them are receiving serious attention from economists, planners, multilateral agencies and governments all over the world (Carter, Camille. 1999).

Human resource development continued to be given priority in support the implementation of a productivity-driven growth, which required highly skilled, trainable and knowledge manpower. Emphasis 
continued to be given to increase accessibility to education at all levels in line with the democratization of the education policy. The high growth rate of the economy was achieved with the price stability and since 1995, with virtually full employment before the currency crisis erupted in the late 1997. The rapid expansion in manufacturing increased employment in the sector sharply during the Sixth Pakistan is the seventh largest population in the world and one of the dense populated countries in the world. Pakistan is recently facing lot of problems like unemployment, and slow growth in Agriculture we imported different agriculture related product from the world. Therefore, we have to look at sectors of the economy that have the potential to provide this employment, and simultaneously we have to ensure that the young are provided quality education and training for these more productive sectors of the economy.

\section{Women as Entrepreneurship Business}

Entrepreneur business Development in Turkey and Modalities of Intervention as was the practice of most countries; Turkey also practiced a state directed economy from its inception 1923. Hoping to achieve rapid industrialization it followed import substitution policy and relied on State Economic Enterprises, because it was the common belief that economic growth depended on heavy investment in large, capital-intensive industrial projects. Notwithstanding the imbalance of such a policy there was considerable growth of approximately $7 \%$ per annum. However true to the world pattern the growth declined in the 1970s and a new trend emerged in the 1980s. It was the trend based on free market economy and hence structural reforms were undertaken to give the economy a new shape.

\section{Women's Entrepreneur and SMEs}

Women are highly important contributors to the country's economic and social development. Over the years women participation in the economy has increased rapidly and they constitute almost half of the total population. Since 1990, women's participation in the SMEs business has increased enormously. Even though Pakistan is a newly industrializing country, its female labor force participation rate compares favorably with those of the industrialized countries of the Asia and Pacific region. Women's labor force participation rate has increased over the years, but is still significantly lower than that of men in early decades.

Table 1. Participation Rates by Gender in SMEs Business 2001-2009

\begin{tabular}{|l|l|l|l|l|l|l|l|l|l|}
\hline Gender & $\mathbf{2 0 0 1}$ & $\mathbf{2 0 0 2}$ & $\mathbf{2 0 0 3}$ & $\mathbf{2 0 0 4}$ & $\mathbf{2 0 0 5}$ & $\mathbf{2 0 0 6}$ & $\mathbf{2 0 0 7}$ & $\mathbf{2 0 0 8}$ & $\mathbf{2 0 0 9}$ \\
\hline Male & $\mathbf{3 5}$ & $\mathbf{3 0}$ & $\mathbf{2 9}$ & $\mathbf{3 0}$ & $\mathbf{3 2}$ & $\mathbf{3 0}$ & $\mathbf{2 9}$ & $\mathbf{2 8}$ & $\mathbf{3 0}$ \\
\hline Female & $\mathbf{2 0}$ & $\mathbf{3 5}$ & $\mathbf{3 1}$ & $\mathbf{3 3}$ & $\mathbf{3 5}$ & $\mathbf{3 3}$ & $\mathbf{3 3}$ & $\mathbf{3 5}$ & $\mathbf{3 6}$ \\
\hline Total & $\mathbf{5 5}$ & $\mathbf{6 5}$ & $\mathbf{6 0}$ & $\mathbf{6 3}$ & $\mathbf{6 7}$ & $\mathbf{6 3}$ & $\mathbf{6 2}$ & $\mathbf{6 2}$ & $\mathbf{6 6}$ \\
\hline
\end{tabular}

\section{Survey-2009}

Obviously, it can be seen that employment rates between the three ethnic groups are different: in $2001,55 \%$ of the total work force employed in SME business the share of women is $20 \%$ in sample area. In $2002,65 \%$ of the total work force employed in SME business the share of women is $35 \%$ in sample area, the women of Rural Sindh are so innovative that they can design the different kind of flowers with out using the machines.

In 2003, $6 \%$ of the total work force involves in SME business and the share of women is $31 \%$. In $2004,63 \%$ of the total work force involves in SME business and the share of women is 33\%. In 2005, $67 \%$ of the total work force involves in SME business and the share of women is 35\%. In 2006, $63 \%$ of the total work force involves in SME business and the share of women is $33 \%$. In 2007, $62 \%$ of the total work force involves in SME business and the share of women is $33 \%$. In 2008, $62 \%$ of the total work force involve in SME business and the share of women is $35 \%$. In 2009, $66 \%$ of the total work force involves in SME business and the share of women is $36 \%$. The above figures indicate that share of women in SMEs business in growing compare with male participation in SMEs business in rural areas of Sindh.

\section{Data Collection Methodology}

Data were collected from 500 women at the working in SMEs Business age of 15-65 years old, a number of 250 or 86.2 percent are working. A structured questionnaire was developed as a instrument. Almost 30 percent of the respondents have at least one child at the age of less than 6 years old.

\section{Analysis of Women's Entrepreneur in SMEs Business and Economic Development.}

Economic theory indicates that family decisions regarding labor supply, child care quality, birthrates, and other relevant factors are likely to be affected by the SMEs Business growth in Pakistan. A number of researchers have attempted to estimate the behavioral effects on various family decisions (i.e: the women's decision to participate in the SMEs business) of changes in income, wage rates, and the price of finished products. A sampling of earlier studies includes Heckman 1974; Robin \& Spigelman 1978; Stolzenberg \& Waite 1984; Leibowitz, Waite, \& Witsberger 1987; Berger \& Black 1991; Blau \& Robins 1988, 1989, 1991a, 1991b; Connelly 1992; Hofferth and Wissoker 1992; Leibowitz, Klerman, \& Waite 1992; and Ribar 1992, 1995; Michapolos, Robins, \& Garfinkel 1992; Kimmel 1993, Averett et.al 1997; Powell 1997; and Anderson \& Levine 1999. The more recent research includes Han\& Waldfogel 2001; Baum II 2002, Oishi 2002; Doiron \& Kalb 2005; Viitanen 2005; 
Kimmel \& Powell 2006; and Lockshin \& Fong 2006. For our econometric analysis, we employ the model by Connelly (1992) in which the decision of a woman to participate in the SMEs business is modeled as the outcome of maximizing her utility over goods. Specifically, we estimate a probit model relating employment to wages and child-care costs such that

$\mathrm{L}^{*}=\beta 0+\beta 1 \mathrm{~W}+\beta 2 \mathrm{Pcc}+\beta 3 \mathrm{~A} \varepsilon \mathrm{h}$

3210

$\mathrm{L}=1$ (participates) if $\mathrm{L}^{*}>0$

$\mathrm{L}=0$ (does not participate) otherwise where $\mathrm{L}^{*}$ is the labor supply of women, $\mathrm{W}$ is the market wage rate, Pcc is the hourly cost of SMEs product, and A is a vector of other observed determinants. For other observable determinants A, we use the age, years of education, working experience, husbands income, number of children, and dummy variable showing the marital status, urban/rural areas, health, and wheater or not they live in their born-area. The problem is that women is not observed in the samples that are not employed. Similarly $\mathrm{P}$ is observed only in the sample of who left children at the formal care. Therefore, we make estimation of the market wages and price of child care. The sample size used for estimation was 300 women. Summary statistics of the variables used are as shown in Table 5.

With a sample size of 3000 women at the working in SMEs Business age of 15-65 years old, a number of 250 or 86.2 percent are working during the survey. Almost 30 percent of the respondents have at least one child at the age of less than 6 years old.

Table 2. Summary Statistics

\begin{tabular}{|c|c|c|c|}
\hline Variables $\mathbf{n}=\mathbf{3 0 0}$ & & Frequencies & Percent \\
\hline \multirow[t]{4}{*}{ Location } & Jacobabad & 200 & 40 \\
\hline & Kashmore & 100 & 20 \\
\hline & Shikarpur & 100 & 20 \\
\hline & Larkana & 100 & 20 \\
\hline Age-Manimum-18 & 19-30 & 150 & 50 \\
\hline Maximium-50 & 31-50 & 150 & 50 \\
\hline \multicolumn{4}{|l|}{ Race } \\
\hline & Sindhi & 200 & 66.66 \\
\hline & Balouch & 50 & 16.66 \\
\hline & Punjabi & 30 & 10 \\
\hline & Urdu & 20 & 6.66 \\
\hline \multicolumn{4}{|l|}{ Education } \\
\hline & & Male & Female \\
\hline \multirow[t]{4}{*}{ Primary } & Jacobabad & $17 \%$ & $1 \%$ \\
\hline & Kashmore & $20 \%$ & $2 \%$ \\
\hline & Shikarpur & $33 \%$ & $17 \%$ \\
\hline & Larkana & $37 \%$ & $20 \%$ \\
\hline \multicolumn{4}{|l|}{ Secondary } \\
\hline & Jacobabad & $12 \%$ & $0.5 \%$ \\
\hline & Kashmore & $11 \%$ & $1 \%$ \\
\hline & Shikarpur & $22 \%$ & $14 \%$ \\
\hline & Larkana & $28 \%$ & $16 \%$ \\
\hline \multicolumn{4}{|l|}{ University/Graduate } \\
\hline & Jacobabad & $6 \%$ & .33 \\
\hline & Kashmore & $5 \%$ & .4 \\
\hline & Shikarpur & $10 \%$ & $11 \%$ \\
\hline & Larkana & $16 \%$ & $13 \%$ \\
\hline \multirow[t]{5}{*}{ Health Condition } & & Satisfactory & Non-Satisfactory \\
\hline & Jacobabad & $12 \%$ & $88 \%$ \\
\hline & Kashmore & 11 & $89 \%$ \\
\hline & Shikarpur & 40 & 60 \\
\hline & Larkana & 55 & 45 \\
\hline
\end{tabular}


Table 3. Housing Status

\section{Survey-2009}

\begin{tabular}{|l|l|l|l|}
\hline Housing & & Own & Rental \\
\hline & & & \\
\hline & Jacobabad & $\mathbf{9 0 \%}$ & $\mathbf{1 0 \%}$ \\
\hline & Kashmore & $\mathbf{9 3 \%}$ & $\mathbf{7 \%}$ \\
\hline & Shikarpur & $\mathbf{8 0 \%}$ & $\mathbf{2 0 \%}$ \\
\hline & Larkana & $\mathbf{7 5 \%}$ & $\mathbf{2 5 \%}$ \\
\hline & & & \\
\hline
\end{tabular}

Table 4. Working Status

\section{Survey-2009}

\begin{tabular}{|l|l|l|l|}
\hline Working Status & Government Job & SMEs Business & Unemployed \\
\hline & & & \\
\hline Jacobabad & $\mathbf{3 0} \%$ & $\mathbf{2 0} \%$ & $\mathbf{5 0 \%}$ \\
\hline Kashmore & $\mathbf{1 0} \%$ & $\mathbf{3 0} \%$ & $\mathbf{6 0 \%}$ \\
\hline Shikarpur & $\mathbf{2 4 \%}$ & $\mathbf{1 0} \%$ & $\mathbf{6 6 \%}$ \\
\hline Larkana & $\mathbf{3 0 \%}$ & $\mathbf{2 0 \%}$ & $\mathbf{5 0 \%}$ \\
\hline & & & \\
\hline
\end{tabular}

Table 5. Monthly Income from SMEs Business

Survey-2009

\begin{tabular}{|l|l|l|}
\hline Monthly Income & & SMEs Business \\
\hline & & \\
\hline & Jacobabad & Rs.20,000/per family \\
\hline & Kashmore & Rs.20,000/per family \\
\hline & Shikarpur & Rs.30,000/per family \\
\hline & Larkana & Rs.30,000/per family \\
\hline & & \\
\hline
\end{tabular}

Table 6. Probit Model for the Women Participate in SMEs Business

\begin{tabular}{|c|c|c|c|}
\hline Variable & Coefficient & $\mathbf{P}>|\mathbf{t}|$ & Marginal effect \\
\hline - $\quad$ Intercept & -.56677 & 0.78 & \\
\hline \multicolumn{4}{|l|}{ Personal Characteristics } \\
\hline Age & .513879 & 0.01 & .344465 \\
\hline Years of Education & .00987765 & 0.909 & .00098877 \\
\hline Status & -0.99876 & 0.878 & .098866 \\
\hline Health & .4123467 & 0.0067 & -0.4322 \\
\hline Birth of Origin & -.87654 & 0.177 & -76543 \\
\hline Experience & .1988766 & 0.7654 & -0.44556 \\
\hline Income & .98766 & 66689 & .097655 \\
\hline Marketing & -0.8765 & -0.8876 & -86544 \\
\hline Women Wages in SMEs Business & -0.877665 & 0.0012 & -7654 \\
\hline Cost on SMEs products & -76554 & 0.2345 & -765433 \\
\hline Log likelihood & & -865433 & \\
\hline Pseudo & & 0.7654 & \\
\hline
\end{tabular}

As the theory predicts, years of education and working experience are significantly positive indicating that higher education or having more experience raise the probability of participation. As a proxy to wages, having more education means greater possibility of getting better jobs, hence have higher wages. But the situation in SMEs business is entirely different in case f education and wages. Women are getting low wages and due to non 
availability of market facility they are paying low wages. The negative impact of husbands' income and having children at the age of 0-6 years old are also significant. High income of other household member, raises the reservation wage of mothers, thus lowers the probability of participation when the objective of working is to help family's financial need. The impact of childcare on mothers' labor force participation is significant but not as the theory predicted. The probability of participation in labor force is significantly higher for women who lived in the urban areas where jobs opportunities are greater compared to the rural.

\section{Factors Influencing the Increase of Employed Women}

The increase in the participation rate of women in SMEs business in Pakistan could to a certain extent be explained by the above analysis because due to factors that women has no access to market and other amentias facilities. The increase in the female labor force participation may be attributable to improving economic incentives in employment and policies favoring the employment of women. In addition, the combined effects of improved maternal and child health care, access to family planning services, increased years of schooling, leading to arise in the average age at marriage, have allowed women to take advantage of the increased employment opportunities

Despite their significant role of women in SMEs Business, they have been largely ignored in the government's programs until recently, and the effects of the current programs focusing on income-generating activities such as food processing and handicrafts remain to be seen, iii) Women's low earning can be attributed to lifetime choices between work and family formation (from the viewpoint of labor supply) and to employment discrimination (from the viewpoint of labor demand). Since women usually have a greater role than men in caring for the family, they may invest less in their own education and may work for shorter periods and in occupations that require fewer hours or less effort than men. This combined with interruptions in labor-force participation limits women's access to better jobs and promotions. Furthermore, employers, in turn, may invest less in nurturing women's skills through training or education because women are expected to drop out of the labor force while they are raising young children or, in many circumstances, to stop all work outside the home once they are married.

\section{Conclusion}

Much progress has been achieved in the past few decades in narrowing the gender gap in Pakistan. It can be shown in the developments in women's roles, both in absolute and relative terms, in the major socioeconomic aspects of the country's development: increasing rates of female labor force participation, gains in productive activities of women and their strengthened economic standing and their increased participation in education. Pakistan's impressive economic growth has been accompanied by the greater

participation of women in the formal workforce and in a range of other activities. There are equal opportunities for employment for both men and women workers in Pakistan. Based on the Labor Force Survey, in the first quarter of year 2002, women a made up 35.5 per cent of the labor force. Policy statements in the Government's also provide opportunities for women in SMEs business and economic participation as well as participation in education and training.. Viewed from this perspective, women as active actors, in both the private and public spheres-should be trained with their male counterparts focusing not only on their domestic role but also on their productive role.

\section{References}

Anderson, P.M. \& P.B. Levine. (1999). Child Care and Mother's Employment Decisions. Working Paper for National Bureau of Economic Research http://www.nber.org/papers/w7058.

Averett, S.L., H.E. Peter \& D. M. Waldman. (1997). Tax Credits, Labor Supply and Child Care. The Review of Economics and Statistics, 79(1), 125-36.

Baum II, C. L. (2002). A Dynamic Analysis of the Effect of Child Care Costs on the Work Decisions of Low-income Mothers with Infants. Demography. 39 (1), 139-64

Berger, M.C. \& D.A. Black. (1991). Child Care Subsidies, Quality of Care, and the Labor Supply of Low Income, Single Mothers, The Review of Economics and Statistics, 70, 635-41

Blau, D. \& P. Robins. (1988). Child-care Costs and Family Labor Supply. The Review of Economics and Statistics, 70 (3), 374-81.

Bormann, M.K, Quarm, D. \& Gideonse,S. (1984). Women in the workplace: Effects on families. Norwood, New Jersey: Ablex Publishing Corporation.

Connelly, R. (1992). The Effect of Child Care Costs on Married Women's Labor Force Participation. The Review of Economics and Statistics, 74(1), 83-90.

Doiron, D \& G. Kalb. (2005). Demands for Child Care and Household Labor Supply in Australia. The Economic Record, 81(254), 215-236

Han, Wenjui \& J. Waldfogel. (2001). Child Care Costs and Women's Employment: A Comparison of Single and Married Mothers with Pre-School-Aged Children. Social Science Quarterly 82(3), 552-68. 
Heckman, J. (1974). Effects of Child Care Programs on Women's Work Effort. Journal of Political Economy, 82, s136-s163.

Hofferth, S. L. \& D. A. Wissoker. (1991). Price and Quality in Child Care Choice. Journal of Human Resources, 27(1), 70-111.

Kaufman, E.B. (1994). The economics of labor markets. 4th Edition. Georgia State Universities: The Dryden Press.

Kimmel, J. (1993). Child Care Costs As a Barrier to Employment for Single and Married Mothers. The Review of Economics and Statistics, 287.

Kimmel, J \& L. M. Powell. (2006). Nonstandard Work and Child Care Choices of Married Mothers. Eastern Economic Journal, 32 (3), 397-419.

Lehar, H., Abdullah, M. \& Anas, Y. (1998). Pakistann Economics. Institut Teknologi Mara: Shah Alam

Leibowitz, A; J. A. Klerman \& L. J. Waite. (1992). Employment of New Mothers and Child Care Choice: Differences by Children's Age. Journal of Human Resources. 27(1) 112-133

Leibowitz, A; L. J. Waite \& C. Wittsberger. (1988). Child care for Preschoolers: Differences by Child's Age. Demography, 205-220.

Lokshin, M. \& M. Fong. (2006). Women's labor Force Participation and Child Care in Romania. Journal of Development Studies, 42 (1), 90-109.

Michalopoulos, C.; P.Robins \& I. Garfinkel. (1992). A Structural Model of Labor Supply and Child Care Demand. Journal of Human Resources, 27, 166-203.

Oishi, A. S. (2001). The Effect of Childcare Costs on Mothers' Labor Force Participation. Paper for the Distribution of Income Project 1999-2001, s51-s65.

Powell, L.M. (1998). Part-time versus Full-time Work and Child Care Costs: Evidence for Married Mothers. Applied Economics, 30(4), 503-11.

Ribar, D. (1992). Child Care and the Labor Supply of Married Women. Journal of Human Resources, 27, No.1, 134-65.

Robins, P. K. \& R. G. Spiegelman. (1978). An Econometric Model of the Demand for Child Care. Economic Inquiry, 16, 83-94.

Stolzenberg, R.M. \& L. J. Waite. (1988). Local Labor Market, Children and Labor Force Participation of Wives. Demography, 21(2), 157-68.

Stromquist, P.N \& Monkmen, K. (1998). Women in the third world: An encyclopedia of the contemporary issues. New York \& London: Garland Publishing Incorporation

Viitanen, T. K. (2005). Cost of Childcare and Female Employment in the UK. Labor 19 (Special Issue), 149-170. 